\title{
Macula of Saccule
}

National Cancer Institute

\section{Source}

National Cancer Institute. Macula of Saccule. NCI Thesaurus. Code C33045.

A vestibular receptor area located on the saccule of the membranous labyrinth of the inner ear, which functions to detect vertical linear acceleration and position of the head. 